E3S Web of Conferences 1, 09009 (2013)

DOI: $10.1051 / \mathrm{e} 3$ sconf/20130109009

(c) Owned by the authors, published by EDP Sciences, 2013

\title{
Direct Determination of Zinc, Cadmium, Lead, Copper Metal in Tap Water of Delhi (India) by Anodic Stripping Voltammetry Technique
}

\author{
J. Raj ${ }^{1}$, Anupuma Raina ${ }^{1,}$ Mohineesh ${ }^{1}$ and T. D. Dogra ${ }^{1}$ \\ ${ }^{1}$ Department of Forensic Medicine and Toxicology, All India Institute of Medical Sciences (AIIMS), New Delhi, India- \\ 110029, jaya687@rediffmail.com, +91-99113781
}

\begin{abstract}
Salts of Zinc, Cadmium, Lead and Copper are taken incidentally or accidently and has become of great toxicological importance having toxic effect. In the present study direct determination of $\mathrm{Zn}, \mathrm{Cd}, \mathrm{Pb}$ and $\mathrm{Cu}$ metal was carried out from tap water of Delhi (India) using differential pulse anodic stripping Voltammeter (DPASV) at Hanging mercury dropping electrode (HMDE).Determination of $\mathrm{Zn}, \mathrm{Cd}, \mathrm{Pb}, \mathrm{Cu}$ was done using Ammonium acetate buffer ( $\mathrm{pH} 4.6$ ) with a sweep rate (scan rate) of $59.5 \mathrm{mV} / \mathrm{s}$ and pulse amplitude $50 \mathrm{mV}$ by HMDE by standard addition method. The solution was stirred during pre-electrolysis at $-1150 \mathrm{mV}$ (vs. $\mathrm{Ag} / \mathrm{AgCl}$ ) for 90 seconds and the potential was scanned from $-1150 \mathrm{~V}$ to $+100 \mathrm{~V}$ (vs... $\mathrm{Ag} / \mathrm{AgCl}$ ). As a result the minimum level of $\mathrm{Zn}, \mathrm{Cd}, \mathrm{Pb}, \mathrm{Cu}$ was Zero and the concentration observed in the tap water sample of Delhi (India) was determined as $0.174 \mathrm{mg} / \mathrm{L}-1,0.001 \mathrm{mg} / \mathrm{L}-1,0.002 \mathrm{mg} / \mathrm{L}-1,0.011 \mathrm{mg} / \mathrm{L}-1$ respectively.
\end{abstract}

Key words: Anodic stripping Voltammetry, Hanging mercury dropping electrode, Heavy Metals, Zinc, Copper, Cadmium, Lead, Tap water.

\section{Introduction}

Metals are elements, present in chemical compounds as positive ions, or in the form of cat-ions ( + ions) in solution. Metals, which have a high atomic weight and a density much greater (at least 5 times) than water are known as heavy metals. Concentration of free metal in tap water is very much helpful in understanding the role of pollutant and nutrient elements (Yilmaz Selehattin et al, 2009) Heavy metals are grouped within the category of environmental toxins and the investigations of these toxic heavy metals such as $\mathrm{Fe}, \mathrm{Mn}, \mathrm{Cu}, \mathrm{Zn}, \mathrm{Co}, \mathrm{Ba}$, and $\mathrm{Ag}, \mathrm{As}, \mathrm{Cd}, \mathrm{Cr}, \mathrm{Hg}, \mathrm{Ni}, \mathrm{Pb}, \mathrm{Sb}$, and $\mathrm{Se}$ place special importance on environmental samples ( Abollino et al 2000, Novotry et al 2000). These heavy metals are much toxic and have tendency to accumulate in the body and may result in chronic damage. The natural concentration of metals in fresh water varies depend upon the metal concentration in the soil (Opydo Jadwiga, 1989) and the underlying geological structures, the acidity of the water, its humus content and particulate matter concentration. There is a very much need to develop trace element analysis technique that allows separation of the different element species prior to trace element analysis." "Industrial and household waste discharges, directly or indirectly through leakages in sewage systems into water sources, cause excessive pollution in surface and underground water" ( Akcay et al 2003)Differential pulse anodic stripping Voltammetry (DPASV) is a powerful and established method for the analysis of trace metals in contaminated samples. It is possible to analyze simultaneously very low levels of several metals such as $\mathrm{Pb}, \mathrm{Cu}, \mathrm{Cd}$ and $\mathrm{Zn}$ using ASV. It can detect levels in the range of part-per-million (ppm) or even part-per-billion (ppb) (i.e., 10-10 M). Several other methods are also used routinely in addition to DPASV, such as Atomic Absorption Spectrometry (AAS) and X-ray fluorescence spectrometry, Inductive coupled plasma, but advantages of using DAPSAV are that it is a successful, new, rapid, simple, selective and inexpensive for qualitative and quantitative determinations of heavy metals. (Farrukh A. et al, 2006)

The other reasons for using DPASAV technique are: It has extremely low detection limits, it works in the presence high salt concentrations, it allows metal speciation and can differentiate between free and complexed metal ions, and it can also analyze non-metals such as anions or organics.

In this study, DPASV technique was used to determine four heavy metals i.e., $\mathrm{Zn}, \mathrm{Cu}, \mathrm{Cd}, \mathrm{Pb}$ in tap water samples of Delhi (India) using Hanging mercury dropping electrode(HMDE) as a working electrode. 
Consequently, the most appropriate conditions were fixed to determine zinc, Copper, Cadmium and lead amount as an analytical application of DPASV on a HMD electrode.

\section{Material and Methods}

\subsection{Instrumentation/accessories and Operating Conditions}

Voltammetric determination of $\mathrm{Zn}, \mathrm{Cd}, \mathrm{Pb}$ and $\mathrm{Cu}$ were performed with Trace Metal Analyzer (797 VA Computrace ,Metrohm AG Ltd, Switzerland) with threeelectrode system consisting Hanging mercury drop electrode(HMDE) as working electrode, Platinum $(\mathrm{Pt})$ as auxiliary electrode and $\mathrm{Ag} / \mathrm{AgCl} / \mathrm{KCl}(3 \mathrm{~mol} / \mathrm{L})$ as reference electrode. The operating parameters are given in Table 1.

Table 1. Operating parameters for the determination of Zinc, Cadmium, Lead and Copper by DPA.

\begin{tabular}{|c|c|}
\hline Parameters & Description \\
\hline Working electrode & $\begin{array}{lll}\text { Hanging } & \text { Mercury } & \text { Dropping } \\
\text { Electrode } & & \\
\end{array}$ \\
\hline Calibration & Standard addition method \\
\hline Number of replications & 3 \\
\hline Drop size & 4 \\
\hline Stirrer speed & $2000 \mathrm{rpm}$ \\
\hline Mode & Differential pulse \\
\hline Initial purge time & $300 \mathrm{~s}$ \\
\hline Addition purge time & $10 \mathrm{~s}$ \\
\hline Deposition potential & $-1.15 \mathrm{~V}$ \\
\hline Deposition time & $90 \mathrm{~s}$ \\
\hline Equilibration time & $10 \mathrm{~s}$ \\
\hline Pulse amplitude & $0.05 \mathrm{~V}$ \\
\hline Start potential & $-1.3 \mathrm{~V}$ \\
\hline End potential & $0.05 \mathrm{~V}$ \\
\hline Voltage step & $0.006 \mathrm{~V}$ \\
\hline Voltage step time & $0.1 \mathrm{~s}$ \\
\hline Sweep rate & $0.06 \mathrm{~V} / \mathrm{s}$ \\
\hline Peak potential $(\mathrm{Zn})$ & $-9.80 \mathrm{~V}$ \\
\hline Peak potential $(\mathrm{Cd})$ & $-0.56 \mathrm{~V}$ \\
\hline Peak potential $(\mathrm{Pb})$ & $-0.38 \mathrm{~V}$ \\
\hline Peak potential $(\mathrm{Cu})$ & $-0.10 \mathrm{~V}$ \\
\hline
\end{tabular}

\subsection{Reagents/Chemicals}

Suprapure acetic acid (Merck Darmstadt, Germany), Nitric acid, Liquor ammonia, ammonium oxalate, and sulphuric acid (Qualigens Fine Chemicals, A Division of GlaxoSmithKline Pharmaceuticals Limited, Mumbai,
India), Ultra pure-deionize water was obtained from Milli-Q (Biocel System, Millipore)

\subsection{Preparation of Supporting Electrolyte (Ammonium acetate buffer)}

$55.5 \mathrm{ml}$ of Suprapure acetic acid was taken in a $500 \mathrm{ml}$ volumetric flask. To this about $100 \mathrm{ml}$ of water was added. $37 \mathrm{ml}$ of Suprapure ammonia was added slowly to the volumetric flask. Ammonia had to be added slowly, because heat will be generated while addition. After the addition the solution was diluted to $500 \mathrm{ml}$ with ultra pure water. The ph of the buffer should be 4.6.

\subsection{Preparation of Standard Solution}

$1 \mathrm{mg} \mathrm{L^{-1 }}$ mixed standard of zinc, cadmium, and lead, copper was prepared for the Voltammetric analysis from stock solution of $1000 \mathrm{mg} \mathrm{L}^{-1}$.

\subsection{Sample collection and Preparation}

Tap water samples were collected in $15 \mathrm{ml}$ graduated centrifuge tubes (Tarson: Cat. No.500030) from the Hundred different areas of Delhi in the month of June 2011 for the determination of $\mathrm{Zn}, \mathrm{Cd}, \mathrm{Pb}$ and $\mathrm{Cu}$ and analyzed in same day.

\subsection{Anodic Stripping Voltammetric measurements}

$10 \mathrm{ml}$ ultra pure water and $1 \mathrm{ml}$ of acetate buffer $(\mathrm{pH} 4.6)$ was taken in polarographic vessel and then the measurement was started under the given parameters Table 1, after this voltamogramme of the blank was recorded. $1 \mathrm{ml}$ of water sample was added to polarographic vessel and then voltamogramme of the sample solution was recorded under the same conditions. After the sample voltamogramme was recorded, $0.1 \mathrm{ml}$ of $1 \mathrm{mg} \mathrm{L}^{-1}$ mixed standard (of $\mathrm{Zn}, \mathrm{Cu}$, and $\mathrm{Cd}$. $\mathrm{Pb}$ ) was added twice and then voltamogramme of the standard was recorded (Fig. 1). ASV is the two step measurement .In the first step the metal ions like Zinc, Cadmium, Lead ,Copper present in the test solution are get deposited on the mercury electrode surface (amalgamation) at deposition potential of $-1150 \mathrm{mV}$. In the second step all the deposited ions are anodically stripped by scanning the potential range from -1150 to $+100 \mathrm{mV}$. All the measurements are done by standard addition technique in which first the sample was taken into the polarographic vessel and the current was measured. After the addition of $100 \mu \mathrm{l}$ of standard soln. the procedure was repeated three times and the current was measured. After all the measurement extrapolation curve was plotted between current vs concentration. The extrapolation curve will show the amount of metals present in the sample solution. All the analysis was done with automatic blank subtraction feature of instrument. Voltamogramme of the standard and sample were shown in Figure 1 and the 


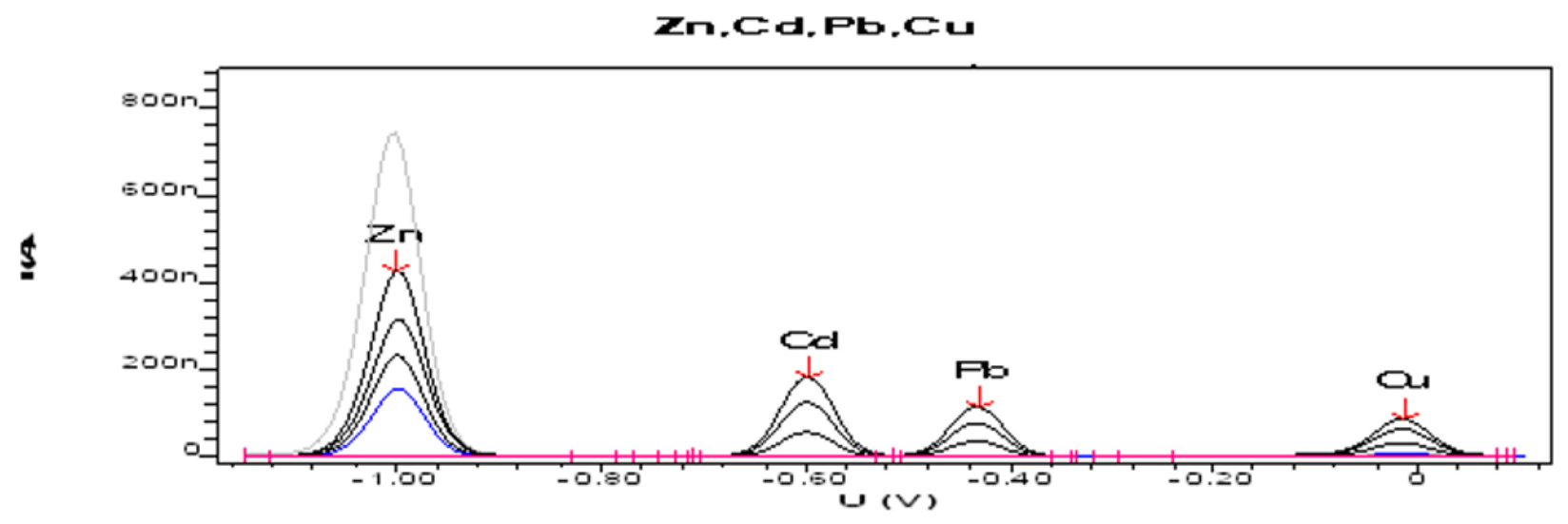

Fig. 1. Voltommogramme obtanined for samples as well as for standards.Condition: scan rate, $59.5 \mathrm{mv} / \mathrm{s} ; \mathrm{Pulse}$ amplitude, $50 \mathrm{mV}$;Deposition potential, $-1150 \mathrm{mV}$ vs $\mathrm{Ag} / \mathrm{AgCl}$; deposition time , 90s, equilibration time,10s;Sacnning range, -1150 to $100 \mathrm{mV}$.

Table 2. Limit value (according to Bis Indian standards, WHO, EPA (Yaymtas et al 2007 and Cpcb report 2006-2007)) and the found values of $\mathrm{Zn}, \mathrm{Cd}, \mathrm{Pb}, \mathrm{Cu}$ heavy Metal in tap water of Delhi, India.

\begin{tabular}{|l|l|l|l|l|l|}
\hline $\begin{array}{l}\text { Heavy } \\
\text { metals }\end{array}$ & \multicolumn{2}{|l|}{$\begin{array}{l}\text { Bis Indian Standards } \\
\text { (IS 105000:1991) }\left(\mathbf{m g ~ L}^{-1}\right)\end{array}$} & $\begin{array}{l}\text { WHO } \\
\left(\mathbf{m g ~ L}^{-1}\right)\end{array}$ & $\begin{array}{l}\text { EPA } \\
\left(\mathbf{m g ~ L}^{-1}\right)\end{array}$ & $\begin{array}{l}\text { Found value of } \mathbf{Z n}, \mathbf{C d}, \mathbf{P b} \text { and Cu in tap water } \\
\text { of Delhi, India }\left(\mathbf{m g L}^{-1}\right)\end{array}$ \\
\hline & Desirable limit & Permissible limit & $\begin{array}{l}\text { Maximum } \\
\text { allowable } \\
\text { concentration }\end{array}$ & & \\
\hline $\mathbf{Z n}$ & 5.0 & 15 & 5.0 & 5.00 & 0.174 \\
$\mathbf{C d}$ & 0.01 & No relaxation & 0.005 & 0.010 & 0.001 \\
$\mathbf{P b}$ & 0.05 & No relaxation & 0.050 & 0.050 & 0.002 \\
$\mathbf{C u}$ & 0.05 & 1.5 & 1.0 & - & 0.011 \\
\hline
\end{tabular}

exploration graph of $\mathrm{Zn}, \mathrm{Cd}, \mathrm{Pb}, \mathrm{Cu}$ were shown in Fig.2,3,4,5.

\section{Results and Discussion}

In this study, the concentration of the zinc, Cadmium, Lead ,Copper metal in the tap water were successfully determined by ASV technique. The concentration of $\mathrm{Zn}(\mathrm{II}), \mathrm{Cd}, \mathrm{Pb}, \mathrm{Cu}$ in tap water of Delhi (India) were found to be $0.174 \mathrm{mg} / \mathrm{L}-1,0.001 \mathrm{mg} / \mathrm{L}-1,0.002 \mathrm{mg} / \mathrm{L}-1$, $0.011 \mathrm{mg} / \mathrm{L} 1 \mathrm{respectively}$. These values were in between the limit values suggested by WHO, and EPA (Yaymtas et al 2007 and Cpcb report 2006-2007) (Table 2). Consequently, it is understood that the concentration of $\mathrm{Zn}$ (II), $\mathrm{Cd}, \mathrm{Pb}, \mathrm{Cu}$ in tap water of Delhi(India) have no influence on the human health. Voltamogramme of the standard and sample were shown in Figure 1. The sensitivity was calibrated by standard additions to the sample and the metal concentrations initially were calculated by exploration The extraploration graph of $\mathrm{Zn}, \mathrm{Cd}, \mathrm{Pb}, \mathrm{Cu}$ were shown in Fig.2,3,4,5. Voltammetric apparatus is used on quantitative mode, it automatically requires one sample to be added to the Voltammetric cell and then three standards to be added and finally, the Metrohm software plots the current-concentration value.
Consequently, linear calibration range was automatically obtained as being related to quantitative mode of the Voltammetric unit.

Many analytical methods has been published for the determination of Zinc, Cadmium, Lead and Copper but using one method in DPASAV for the analysis of four metal combined respectively $\mathrm{Zn}, \mathrm{Cd}, \mathrm{Pb}, \mathrm{Cu}$ is presented in this work. The advantages of the proposed Voltammetric method over the other known techniques( AAS, ICPOES,etc) are that it is a successful, new, rapid, simple, selective and inexpensive technique for quantitative and qualitative determination of heavy metals and it has extremely low detection limits and can also works in the presence of high salt concentrations.

\section{Conclusion}

In this work, the most appropriate conditions were fixed to determine the amount of $\mathrm{Zn}, \mathrm{Cd}, \mathrm{Pb}$, and $\mathrm{Cu}$ through DAPSAV using single method on hanging mercury drop electrode (HMDE). Direct determination of $\mathrm{Zn}, \mathrm{Cd}, \mathrm{Pb}$, $\mathrm{Cu}$ in the tap water sample is possible by DAPSAV. Under working conditions the amount of $\mathrm{Zn}, \mathrm{Cd}, \mathrm{Pb}, \mathrm{Cu}$ in tap water sample has been successfully determined. It can be very useful for human health concern. This 


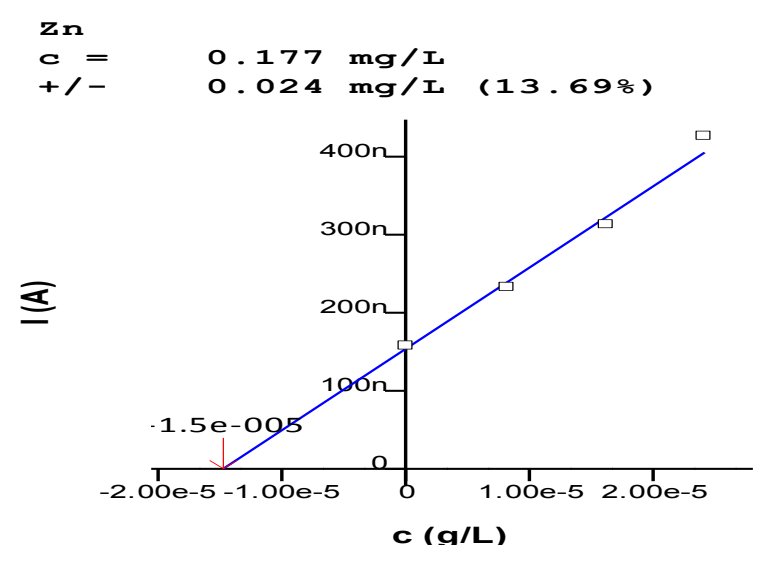

Fig. 2. Extrapolation graph of $\mathrm{Zn}$

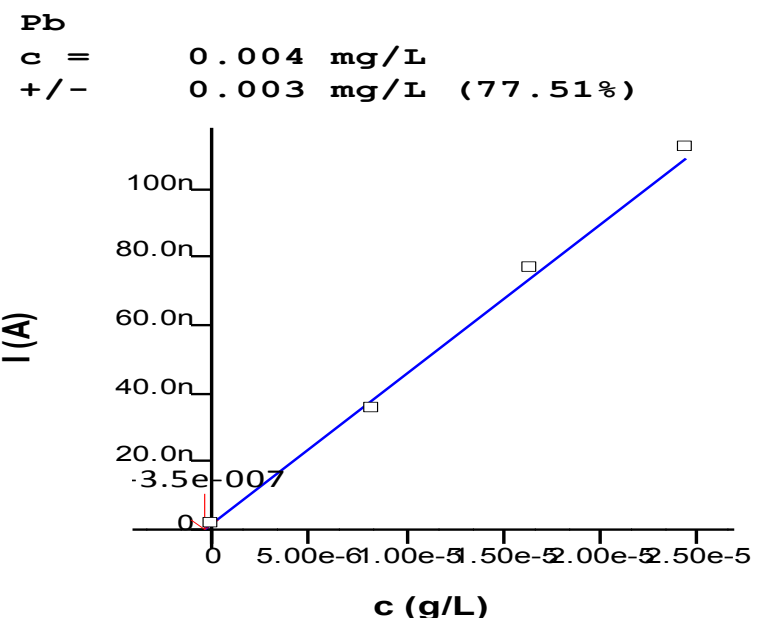

Fig. 4. Extrapolation graph of $\mathrm{Pb}$

method is rapid, sensitive and less costly as compared to other analytical methods.

\section{References}

Abollino A. M., Sarzani C, Mentasti E, The retention of metal species by different solid sorbents: Mechanisms for heavy metal speciation by sequential three column uptake Anal. Chim. Acta, 411 (2000) 223.

Akcay H, Oguz A, Karapire C. Study of heavy metal pollution and speciation in Buyak Menderes and Gediz river sediments. Water Research 37 (2003) 813-822.

Farrukh A, Iqbal A, Zafar M . Antioxidant and free radical scavenging properties of twelve traditionally used Indian medicinal plants. Turk. J Biol. 30 (2006) 177-83.

Novotry K , Turzikova A, Komarek J, Speciation of copper, lead and cadmium in aquatic systems by

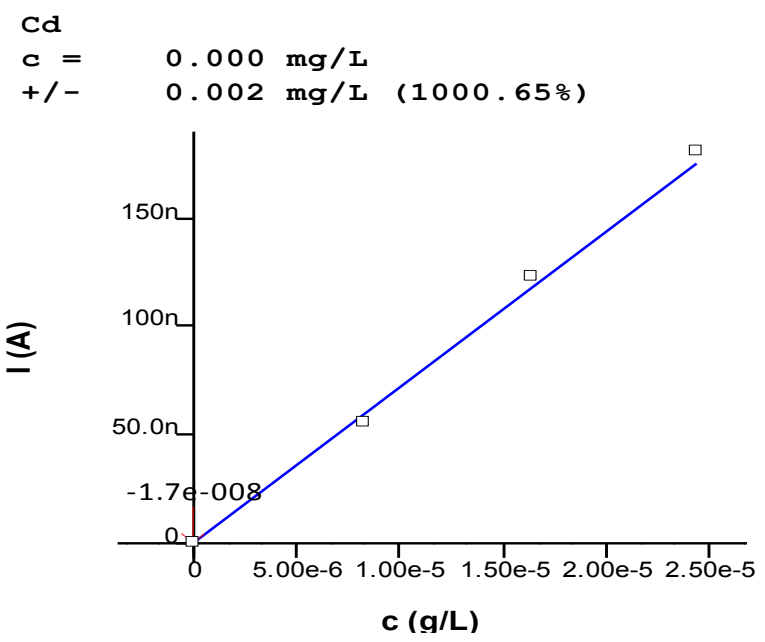

Fig. 3. Extrapolation graph of $\mathrm{Cd}$

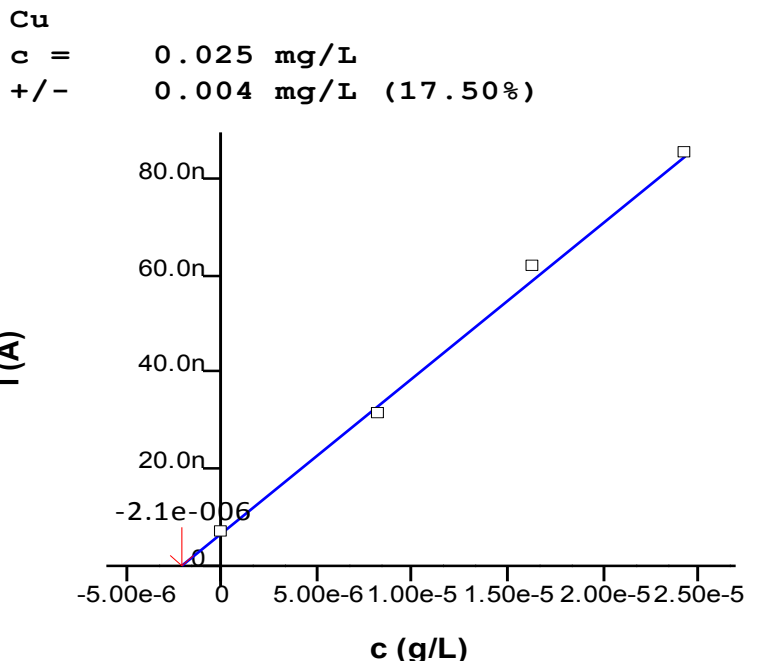

Fig. 5. Extrapolation graph of $\mathrm{Cu}$

circulating dialysis combined with flame AAS. Fresenius. J. Anal. Chem., 366 (2000) 209-212.

Opydo Jadwiga .The determination of $\mathrm{Zn}, \mathrm{Cd}, \mathrm{Pb}$ and $\mathrm{Cu}$ in soil extracts by anodic stripping Voltammetry. Water, Air and Soil pollution 45 (1989) 43-48.

Status of ground water quality in India-part-I. Ground water quality series GWQS/09/ 2006-2007, www.cpcb.nic.in.

Yayıntas O. T, Yılmaz S, Turkoglu M, Dilgin Y, Determination of heavy metal pollution with environmental physicochemical parameters in waste water of Kocabas Stream (Biga, Canakkale, Turkey) by ICP-AES. Environ. Monit. Assess. 127 (2007) 389-397.

Yilmaz Selehattin, Yagmur Sultan, Saglikoglu Gulsen, Sadikoglu Murat. Direct Determination of Zn Heavy Metal in Tap Water of Canakkale (TURKEY) by Anodic Stripping Voltammetry Technique. Int. J. Electrochem. Sci., 4 (2009) 288-294. 